\section{Analisis Perbandingan Kinerja Keuangan PT. Bank Syariah Mandiri Menggunakan Pendekatan Laba Rugi Dan Nilai Tambah Periode Tahun 2016-2020}

\author{
Nuri Fitriani dan Ratih Puspitasari \\ Program Studi Manajemen, Fakultas Bisnis \\ Institut Bisnis Dan Informatika Kesatuan
}

E-Mail : nuri.fitriani@ibik.ac.id
Financial

Performance Analysis of Sharia Banking

335

Submitted: APRIL 2021

Accepted: JULI 2021

\begin{abstract}
The analysis of the financial performance of Islamic banks so far has been carried out only based on the balance sheet and income statements, not using the value added report as recommended by Baydoun and Willet (2000), an expert in Islamic accounting. The purpose of this research is to review the financial performance of Islamic banking by comparing the results of financial performance using the profit and loss approach and those using added value. To obtain accurate evidence regarding differences in the financial performance of Islamic banking when calculated using the profit and loss approach and added value, it is seen from the ratio of ROA, ROE, LBAP, NPM and BOPO. This study took a sample on the financial statements of PT. Bank Syariah Mandiri 2016 to 2020.
\end{abstract}

Keywords: Financial Performance, Income Statement, Value Added Report

\begin{abstract}
ABSTRAK
Analisis terhadap kinerja keuangan bank syariah selama ini dilakukan hanya didasarkan pada laporan neraca dan laporan laba rugi, belum menggunakan laporan nilai tambah sebagaimana direkomendasikan oleh Baydoun dan Willet (2000), seorang pakar akuntansi syariah. Tujuan dilaksanakannya penelitian ini adalah untuk mengkaji ulang kinerja keuangan perbankan syariah dengan membandingkan antara hasil kinerja keuangan yang menggunakan pendekatan laba rugi dan yang menggunakan nilai tambah. Untuk mendapatkan bukti yang akurat mengenai perbedaan kinerja keuangan perbankan syariah jika dihitung dengan pendeketan laba rugi dan nilai tambah dilihat dari rasio ROA, ROE, LBAP, NPM dan BOPO. Penelitian ini mengambil sampel pada laporan keuangan PT. Bank Syariah Mandiri Tahun 2016 s.d 2020.
\end{abstract}

Kata Kunci : Kinerja Keuangan, Laporan Laba Rugi, Laporan Nilai Tambah

\title{
PENDAHULUAN
}

Bank pada dasarnya merupakan badan usaha yang melakukan penghimpunan dana dari masyarakat dalam bentuk Tabungan, Giro, dan Deposito, serta melakukan penyaluran dana kepada masyarakat dalam bentuk kredit. Dalam sistem perbankan di Indonesia terdapat dua macam sistem Operasional bank yaitu, Bank Konvensional dan Bank Syariah. Sesuai UU No. 21 tahun 2008 tentang Perbankan Syariah, Bank Syariah merupakan bank yang menjalankan kegiatan usaha berdasarkan prinsip syariah, atau prinsip hukum islam yang sudah diatur dalam fatwa Majelis Ulama Indonesia seperti prinsip keadilan dan keseimbangan ('adl wa tawazun), kemaslahatan (maslahah), universalisme (alamiyah), serta tidak mengandung gharar, maysir, riba, zalim, dan obyek yang haram. Selain itu, UU Perbankan Syariah juga mengamanahkan bank syariah untuk menjalankan fungsi sosial dengan menjalankan fungsi seperti lembaga baitul mal, yaitu menerima dana yang berasal dari zakat, infak, sedekah, hibah, atau dana sosial lainnya dan menyalurkannya kepada pengelola wakaf (nazhir) sesuai dengan kehendak pemberi wakaf (wakif). Secara umum terdapat bentuk usaha bank syariah yang terdiri atas Bank Umum

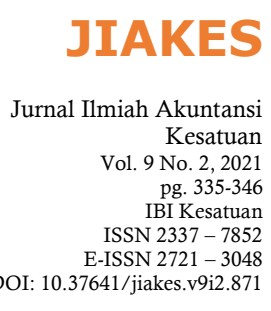


Financial Performance Analysis of Sharia Banking dan Bank Pembiayaan Rakyat Syariah (BPRS), perbedaan pokok (BPRS) yang di larang menerima simpanan berupa giro dan ikut serta dalam lalu lintas sistem pembayaran. Secara kelembagaan bank umum syariah, ada yang berbentuk bank syariah penuh (fullpledged) dan terdapat pula dalam bentuk Unit Usaha Syariah (UUS) dari bank umum konvesional. Pembagian tersebut serupa dengan bank konvesional, dan sebagaimana halnya di atur dalam UU perbankan, UU Perbankan Syariah juga mewajibkan setiap pihak yang melakukan kegiatan penghimpunan dana masyarakat dalam bentuk simpanan atau investasi berdasarkan prinsip syariah harus terlebih dahulu medapatkan izin OJK (Andrianto dan Anang, 2019).

Bank Syariah mempunyai sistem Operasional yang berbeda dengan Bank Konvesional. Dalam Bank Syariah memberikan layanan bebas bunga kepada para nasabah. Dalam sistem Operasional Bank Syariah, penarikan bunga dilarang dalam semua bentuk transaksi apapun. Bank syariah tidak mengenal yang namanya sistem bunga, baik itu bunga yang di peroleh dari nasabah yang meminjam uang atau bunga yang dibayar kepada pemilik dana di bank syariah. Dalam bank syariah hanya mengenal riba atau bagi hasil pada semua akad yang di praktekkan dalam Bank Syariah (Andrianto dan Anang, 2019).

Namun dalam PSAK 101 ( yang sudah direvisi ulang tahun 2014) akuntansi syariah tidak sepenuhnya sesuai dengan karakteristik bank syariah karena hanya memuat sejumlah elemen dalam laporan keuangan bank konvesional, ditambah dengan beberapa laporan, seperti laporan rekonsiliasi pendapatan dan bagi hasil, laporan sumber dan penggunaan dana kebijakan (Sri Nurhayati, Wasilah, 2014). Sedangkan menurut Suryanto. T (2016) Kaitannya dengan pemenuhan akuntanbilitas laporan keuangan bank syariah, dengan belum dimasukannya laporan nilai tambah (Value Added Statment) sebagai laporan keuangan tambahan dalam laporan keuangan bank syariah, maka dari itu perlu diketahui bagaimana pertanggung jawabannya kepada stakeholders. Karena laporan laba rugi ini sangat berdampak terhadap akuntabilitas suatu lembaga perusahaan atau perbankan yang mana diberlakukan kerja sama antara pihak pihak terkait guna merujuk kepada pengaruh yang signifikan terhadap sistem pelaporan keuangan yang lebih baik dari sebelumnya .

Selain itu menurut Dimas dan Melia (2020) laporan laba rugi merupakan laporan yang lebih memperhatikan kepentingan direct stakeholders (pemilik modal), berupa pencapaian profit yang maksimal, dengan mengesampingkan kepentingan dari pihak lain (karyawan, masyarakat, sosial dan pemerintah), sehingga profit yang diperoleh distribusinya hanya sebatas kepada pemilik modal saja. Sementara dengan adanya laporan nilai tambah (value added statment) sebagai laporan keuangan tambahan maka kemampuan bank syariah dalam menghasilkan profitabilitas dihitung dengan memperhatikan kontribusi pihak lain seperti karyawan, masyarakat, pemerintah dan lingkungan. Sehingga profit yang diperoleh dalam distribusinya tidak hanya sebatas pada direct stakeholders saja melainkan juga kepada indirect stakeholder. Oleh karena itu, pakar akuntansi syariah juga merekomendasikan adanya penambahan Laporan Nilai Tambah, dalam laporan keuangan yang diterbitkan oleh lembaga keuangan islam untuk mengetahui kinerja keuangan lembaga ekonomi syariah termasuk dalam hal ini adalah bank syariah, tidak didasarkan pada Laporan Nilai Tambah, agar diketahui secara riil kinerja keuangan yang telah dihasilkan (Rifai, 2013).

Penelitian ini menjelaskan bahwa pendekatan nilai tambah lebih menekankan pada pendistribusian bagi hasil secara adil, sedangkan pendekatan laba rugi hanya kepada pemilik modal saja. Dalam penelitian tersebut menunjukkan bahwa kemampuan bank dalam menghasilkan laba bersih cenderung mengalami peningkatan. Peningkatan tersebut disebabkan oleh praktek manajemen laba. Penilaian kinerja keuangan bank syariah dapat dilakukan dengan menganalisa laporan keuangan yang diterbitkan. Yaitu dengan menganalisa tingkat profitabilitas bank syariah yang bersangkutan, dengan menggunakan lima rasio yaitu Return On Asset (ROA), Return On Equity (ROE), Rasio Perbandingan Antara Total Laba Bersih Dengan Total Aktiva Produktif (LBAP), Net 
Profit Margin (NPM), dan Biaya Operasional terhadap Pendapatan Operasional (BOPO). Semakin besar rasio yang diperoleh berarti kemampuan bank syariah dalam memberikan keuntungan bagi hasil kepada nasabah semakin baik, dan sebaliknya jika perolehan rasio kinerja keuangan kecil berarti kemampuan bank syariah memberikan keuntungan berupa bagi hasil kepada nasabah rendah (Rifai, 2013).

Mengacu pada penelitian sebelumnya (Dimas Pratama dan Melia Frastuti, 2020) secara keseluruhan profitabilitas perbankan syariah menunjukkan dengan ada nilai tambah (value added statment) akan memberikan nilai tambah (laba) yang lebih tinggi dibandingkan dengan laba yang diperoleh berdasarkan Laba Rugi. Hal ini sejalan dengan Rifai (2013) dalam laporan keuangan yang diterbitkan oleh lembaga keuangan Islami untuk mengetahui kinerja keuangan lembaga ekonomi syariah, tidak cukup hanya didasarkan pada Neraca dan Laporan Laba Rugi saja akan tetapi juga perlu didasarkan pada Laporan Nilai Tambah, agar diketahui secara riil kinerja keuangan.

Berdasarkan latar belakang iniliah, peneliti tertarik untuk mengkaji ulang bagaimana kinerja keuangan perbankan syariah jika dihitung dengan pendekatan laba rugi dan nilai tambah, dan untuk mendapatkan bukti empiris mengenai perbedaan kinerja keuangan perbankan syariah jika dilihat dari rasio $R O A, R O E$, Rasio Perbandingan Antara Total Laba Bersih dengan Total Aktiva Produktif, Net Profit Margin (NPM), Biaya Operasional terhadap Pendapatan Operasional (BOPO).

Tujuan yang hendak di capai dalam penelitian ini adalah :

1. Untuk mengetahui apakah terdapat perbedaan yang signifikan terhadap rasio Return On Assets (ROA) pada PT. Bank Syariah Mandiri jika dianalisis menggunakan pendekatan laba rugi dan nilai tambah.

2. Untuk mengetahui apakah terdapat perbedaan yang signifikan terhadap rasio Return On Equity (ROE) pada PT. Bank Syariah Mandiri jika dianalisis menggunakan pendekatan laba rugi dan nilai tambah.

3. Untuk mengetahui apakah terdapat perbedaan yang signifikan terhadap rasio Total Laba Bersih dengan Total Aktiva Produktif (LBAP) pada PT. Bank Syariah Mandiri jika dianalisis menggunakan pendekatan laba rugi dan nilai tambah.

4. Untuk mengetahui apakah terdapat perbedaan yang signifikan terhadap Net Profit Margin (NPM) pada PT. Bank Syariah Mandiri jika dianalisis menggunakan pendekatan laba rugi dan nilai tambah.

5. Untuk mengetahui apakah terdapat perbedaan yang signifikan rasio Biaya Operasional terhadap Pendapatan Operasional (BOPO) pada PT. Bank Syariah Mandiri jika dianalisis menggunakan pendekatan laba rugi dan nilai tambah.

\section{Pengembangan Hipotesis}

Menurut Elyanti (2014) kerangka pemikiran dalam penelitian ini adalah tentang bagaimana cara menghitung perbedaan kinerja keuangan PT. Bank Syariah Mandiri berdasarkan pada pendekatan laba rugi dan nilai tambah jika diukur dengan menggunakan 5 rasio yang terdiri dari ROA, ROE, LBAP, NPM dan BOPO . Yang masing-masing variabelnya akan dijelaskan sebagai berikut:

a) Dengan pendekatan laba rugi merupakan gambaran mengenai kemampuan kinerja keuangan PT. Bank Syariah Mandiri dalam menghasilkan keuntungan atau laba.

b) Dengan pendekatan nilai tambah merupakan gambaran mengenai kemampuan kinerja keuangan PT. Bank Syariah Mandiri dalam menghasilkan nilai tambah.

c) Rasio ROA digunakan untuk mengukur efektifitas bank dalam memperoleh keuntungan secara keseluruhan, berdasarkan pendekatan laba rugi dan nilai tambah.

d) Rasio ROE digunakan untuk mengukur kemampuan bank memperoleh laba yang efisiensi secara keseluruhan operasional melalui penggunaan modal sendiri, berdasarkan pendekatan laba rugi dan niali tambah.

e) Rasio LBAP digunakan untuk mengetahui kemampuan bank dalam mengelola dana yang diinvestasikan secara keseluruhan aktiva produktif, berdasarkan pendekatan laba rugi dan nilai tambah.
Financial Performance of Sharia Banking

\section{7}


Financial Performance Analysis of Sharia Banking

\section{8}

f) Rasio NPM digunakan untuk mengetahui kemampuan bank dalam menghasilkan laba berseih sebelum pajak ditinjau dari sudut operating incomenya, berdasarkan pendekatan laba rugi dan nilai tambah.

g) Rasio BOPO digunakan untuk mengukur kemampuan manajemen bank dalam menghasilkan biaya operasional terhadap pendapatan operasional, berdasarkan pendekatan laba rugi dan nilai tambah.

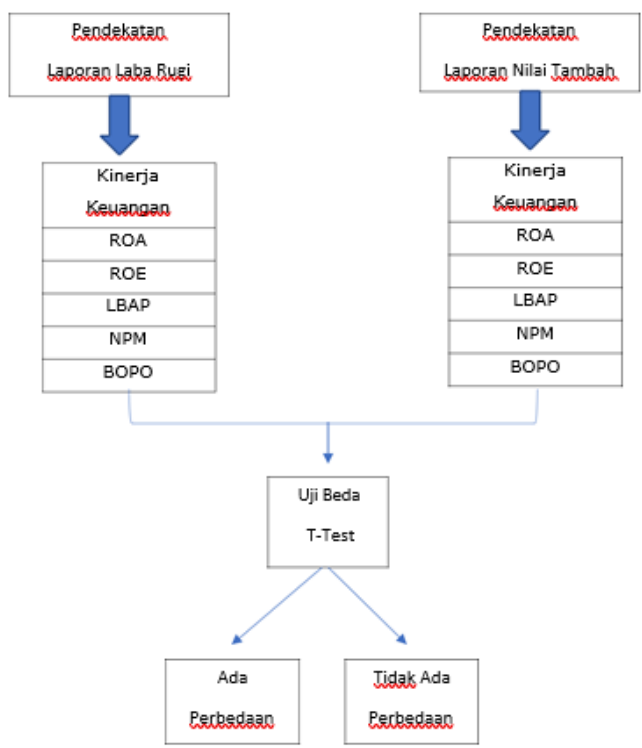

Gambar 1. Kerangka Pemikiran Hipotesis Penelitian

Berikut hipotesis penelitian ini:

1) Diduga terdapat perbedaan rasio ROA pada PT. Bank Syariah Mandiri, berdasarkan pendekatan laba rugi dan nilai tambah.

2) Diduga terdapat perbedaan rasio ROE pada PT. Bank Syariah Mandiri, berdasarkan pendekatan laba rugi dan nilai tambah.

3) Diduga terdapat perbedaan rasio total laba bersih dengan total aktiva produktif pada PT. Bank Syariah Mandiri, berdasarkan pendekatan laba rugi dan nilai tambah.

4) Diduga terdapat perbedaan rasio NPM pada PT. Bank Syariah Mandiri, berdasarkan pendekatan laba rugi dan nilai tambah.

5) Diduga terdapat perbedaan BOPO pada PT. Bank Syariah Mandiri, berdasar pendekatan laba rugi dan nilai tambah.

\section{METODE PENELITIAN}

Jenis Penelitian ini adalah penelitian komparatif dengan pendekatan kuantitatif. Objek analisis penelitian ini meliputi laporan keuangan yang terdiri dari Laba Rugi dan Nilai tambah yang dihitung dengan menggunakan variabel ROA, ROE, LBAP, NPM dan BOPO, selama kurun waktu 5 tahun yaitu periode tahun 2016-2020, dan yang menjadi subjek dalam penelitian ini adalah PT Bank Syariah Mandiri. Objek penelitian ini adalah laporan keuangan PT. Bank Syariah Mandiri yang disusun dalam bentuk tahunan yang terdiri dari neraca, laporan laba rugi, laporan kualitas aktiva produktif, dan catatan atas laporan keuangan. Sementara unit penarikkan sampelnya yaitu PT. Bank Syariah Mandiri selama 5 periode (2016-2020). Teknik pemilihan sampelnya menggunakan Proportionate Stratified Random Sampling karena teknik ini digunakan bila populasi mempunyai anggota atau unsur yang tidak homogen dan berstrata secara profesional. Metode Pengujian Data penelitian ini terdiri dari: Uji statistik deskriptif yang dilakukan untuk mengetahui dan melihat karakteristik data, dimana dalam penelitian ini menggunakan mean, standar deviasi, nilai minimum dan nilai maksimum dari masingmasing rasio yang mewakili laba rugi dan nilai tambah, Uji normalitas adalah untuk melihat apakah nilai residual terdistribusi nomal atau tidak. Model regresi yang baik adalah memiliki nilai residual yang terdistribusi normal. Jadi uji normalitas bukan dilakukan pada 
masing-masing variabel tetapi pada nilai residualnya (Albert Kurniawan, 2014). Pengujian ini bertujuan untuk mengetahui apakah data penelitian ini berdistribusi normal atau tidak dan untuk mengujinya dapat digunakan uji Kolmogrov-Smirnov dengan cara membandingkan signifikansi dari uji tersebut terhadap besaran $\alpha 5 \%$ apabila signifikansi dari residual lebih besar dari $5 \%$ berarti data berdistribusi normal, Uji beda T-test ini digunakan untuk menentukan apakah kedua sampel yang tidak berhubungan memiliki rata-rata yang berbeda. Dalam penelitian ini menggunakan uji pendekatan parametrik yaitu uji paired sampel t-test atau uji t sampel berpasangan yang digunakan untuk menguji hipotesis sama atau berbeda. Data berasal dari dua pengukuran atau dua periode pengamatan yang berbeda yang diambil subjek yang dipasangkan (Ghazali, 2016). Uji $t$ test dilakukan dengan cara membandingkan perbedaan antara laba rugi dan nilai tambah.

Hipotesis yang dibangun adalah

a. ${ }_{0}$ diterima :Ada perbedaan yang siginifikan

b. ${ }_{0}$ ditolak : Tidak ada perbedaan yang signifikan Pengambilan keputusan

a. Jika Profitabilitas $>0.05$, maka ${ }_{0}$ ditolak

b. Jika Profitabilitas $\leq 0.05$, maka 0 diterima

Data yang dibutuhkan dalam penelitian ini adalah data kuantitatif yang merupakan data sekunder. Adapun penjelasan mengenai data sekunder tersebut adalah. Data sekunder merupakan data yang dikumpulkan melalui pihak kedua, biasanya diperoleh melalui instansi yang bergerak dibidang pengumpulan data seperti Badan Pusat Statistik dan lainlain. Data sekunder dalam penelitian ini ialah data yang di dapatkan dari Laporan Keuangan PT. Bank Syariah Mandiri dari tahun 2016-2020. Metode penelitian menggunakan pengumpulan data studi pustaka dengan mengakaji buku-buku atau literatur dan jurnal ilmiah untuk memperoleh landasan teoritis yang kuat dan menyeluruh tentang perbankan syariah.

\section{HASIL DAN PEMBAHASAN \\ Hasil Analisis deskriptif Data Penelitian}

Uji statistik deskriptif dilakukan untuk mengetahui dan memperoleh penelitian terkait data yang digunakan dalam penelitian dari mean, standar deviasi, varian, nilai minimum, range dan sebagainya (Ghozali, 2016).

Analisis Statistik Deskriptif Dengan Pendekatan Laba Rugi

Tabel 1. Statistik Deskriptif Variabel dengan Pendekatan Laba Rugi

\begin{tabular}{|c|c|c|c|c|c|}
\hline & $\mathrm{N}$ & Minimum & Maximum & Mean & Std. Deviation \\
\hline ROA & 5 & .00410 & .01140 & .0074400 & .00366847 \\
\hline ROE & 5 & .04980 & , 13790 &, 0892600 & .04310995 \\
\hline LBAP & 5 & .33440 & 1,13730 & .6601000 & .32241093 \\
\hline NPM & 5 & .05010 & .16610 & .0993400 & .05575184 \\
\hline BOPO & 5 & 2,92570 & 5,53260 & 4,2819200 & 1,26310389 \\
\hline Valid N (listwise) & 5 & & & & \\
\hline
\end{tabular}

Berdasarkan tabel 1. variabel ROA jika dihitung menggunakan pendekatan laba rugi memiliki nilai minimum 0,00410 dan nilai maksimum 0,01140 . Nilai rata- rata sebesar 0,0074400 dengan standar deviasi sebesar 0,00366647 dapat diartikan adanya variasi yang terdapat dalam ROA. Angka 0,0074400 tersebut menunjukkan angka yang relatif besar karena simpangan baku pada ROA lebih rendah dari 0,0074400 yaitu 0,00366647. Hal ini mengindentifikasikan bahwa efektivitas perusahaan dalam memanfaatkan besarnya aset yang dimiliki untuk menciptakan laba adalah baik sehingga nilai ROA menjadi besar. Pada Variabel ROE jika dihitung menggunakan pendekatan laba rugi memiliki nilai minimum 0,04990 dan nilai maksimum 0,13790 . Nilai rata-rata sebesar 0,0892600 dengan standar deviasi sebesar 0,04310995 dapat diartikan badanya variasi yang dalam ROE. Angka 0,0892600 tersebut menunjukkan angka yang relatif besar karena simpangan baku
Financial

Performance of

Sharia Banking 
Financial Performance Analysis of Sharia Banking pada ROE lebih rendah dari 0,0892600 yaitu 0,04310095. Hal ini mengidikasikan bahwa efektifitas perusahaan dalam memanfaatkan kontribusi pemilik dalam menciptakan laba adalah baik.

Pada variabel perbandingan laba bersih dengan aktiva produktif (LBAP) jika dihitung dengan menggunakan pendeketan laba rugi memiliki nilai minimum 0,33440 dan nilai maksimum 1,13730. Nilai rata-rata sebesar 0,6601000 dengan standar deviasi sebesar 0,32241093 , dapat diartikan adanya variasi yang terdapat dalam jumlah perbandingan laba bersih dengan kualitas aktiva produktif. Angka 0,6601000 tersebut menunjukkan angka yang relatif besat karena simpangan baku lebih rendah dari 0,6601000 yaitu 0,32241093 . Hal ini mengindikasikan bahwa efektifitas perusahaan dalam memanfaatkan aktiva produktif yang dimiliki untuk menciptakan laba adalah baik. Pada variabel Net Profit Margin (NPM) jika dihitung dengan menggunakan pendekatan laba rugi memiliki nilai minimum 0,05010 dan nilai maksimum 0,16610. Nilai rata-rata sebesar 0,0993400 dengan standar deviasi 0,05575184 dapat diartikan adanya variasi yang terdapat dalam NPM. Angka 0,0993400 menunjukkan angka yang relatif besar karena simpangan baku NPM lebih rendah dari 0,0993400 yaitu 0,05575184. Hal ini mengindikasikan bahwa kemampuan bank dalam menghasilkan laba bersih adalah baik sehongga total pendapatan menjadi besar.

Pada variabel Biaya Operasional terhadap Pendapatan Operasional (BOPO) jika dihitung dengan pendekatan laba rugi memiliki nilai minimum 2,92570 dan nilai maksimum 5,53260. Nilai rata-rata 4,2819200 dengan standar deviasi sebesar 1,26310389, dapat diartikan adanya variasi yang terdapat dalam BOPO. Angka 4,28199200 tersebut menunjukkan angka yang relatif besar karena simpangan baku pada BOPO lebih rendah dari 4,28199200 yaitu 1,26310389. Hal ini mengindikasikan bahwa tingkat efisiensi dan kemampuan bank dalam melakukan kegiatan operasinya kurang baik.

Analisis Statistik Deskriprif Dengan Pendekatan Nilai Tambah Tabel 2. Statistik Deskriptif Variabel Dengan Pendekatan Nilai Tambah

\begin{tabular}{|c|c|c|c|c|c|}
\hline & $\mathrm{N}$ & Minimum & Maximum & Mean & Std. Deviation \\
\hline$\overline{\mathrm{ROA}}$ & 5 & 71880 & 81110 & 7856800 & 03850347 \\
\hline $\mathrm{ROE}$ & 5 & 8,41510 & 10,00300 & 9,5035000 & 63526882 \\
\hline$\overline{\mathrm{LBAP}}$ & 5 & 53740 &, 59400 &, 5737600 &, 02265972 \\
\hline$\overline{\mathrm{NPM}}$ & 5 & 9,66120 & 10,56290 & 10,1955200 & ,40049488 \\
\hline $\mathrm{BOPO}$ & 5 & 2,92570 & 5,53260 & 4,2819200 & 1,26310389 \\
\hline Valid N (listwise) & 5 & & & & \\
\hline
\end{tabular}

Berdasarkan tabel 2 diatas, variabel ROA jika dihitung dengan menggunakan pendekatan Nilai Tambah memiliki nilai minimum 0,71880 dan nilai maksimum 0,81110. Nilai rata-rata sebesar 0,7856800 dengan standar deviasi sebesar 0,03850347 dapat diartikan adanya variasi yang terdapat dalam ROA. Angka 0,7856800 tersebut menunjukkan angka yang relatif besar karena simpangan bahan baku pada ROA lebih rendah dari 0,7856800 yaitu 0,03850347 . Hal ini mengindikasikan bahwa efektifitas perbankan syariah dalam memanfaatkan aset yang dimiliki untuk menciptakan laba adalah baik sehingga nilai ROA menajdi besar. Pada variabel ROE jika dihitung menggunakan pendekatan Nilai Tambah memiliki nilai minimum 8,41510 dan nilai maksimum 10,00300. Nilai rata-rata sebesar 9,5035000 dengan standar deviasi sebesar 0,63526882, dapat diartikan adanya variasi yang terdapat dalam ROE. Angka 9,5035000 menunjukkan angka yang relatif besar karena simpangan baku pada ROE lebih rendah dari 9,5035000 yaitu 0,63526882. Hal ini mengindikasikan bahwa perbankan syariah telah efektif memanfaatkan kontribusi pemilik yang ada untuk menciptakan laba.

Pada variabel perbandingan laba bersih dengan aktiva produktif (LBAP) jika dihitung dengan pendekatan Nilai Tambah memiliki nilai minimum 0,53740 dan nilai maksimum 0,59400 . Nilai rata-rata sebesar 0,5737600 dengan standar deviasi sebesar 0,02265972, dapat diartikan adanya variasi yang terdapat dalam LBAP.

Angka 0,5737600 tersebut menunjukkan angka yang relatif besar karena simpangan baku pada LBAP lebih rendah dari 0,5737600 yaitu 0,02265972. Hal ini mengindikasikan 
bahwa efektivitas perbankan syariah dalam memanfaatkan aktiva produktif yang memiliki untuk menciptakan laba adalah baik.

Pada variabel Net Profit Margin (NPM) jika dihitung dengan pendekatan Nilai Tambah memiliki nilai minimum 9,66120 dan nilai maksimum 10,56290. Nilai rata-rata sebesar 10,1955200 dengan standar deviasi sebesar 0,40049488, dapat diartikan adanya variasi yang terdapat dalam NPM. Angka 10,1955200 tersebut menunjukkan angka yang relatif besar karena simpangan baku pada NPM lebih rendah dari 10,1955200 yaitu 0,40049488. Hal ini mengindikasikan bahwa kemampuan perbankan syariah dalam menghasilkan laba bersih adalah baik sehingga total pendapatan menjadi besar. Pada variabel Biaya Operasional terhadap Pendapatan Operasional (BOPO) jika dihitung dengan pendekatan laba rugi memiliki nilai minimum 2,92570 dan nilai maksimum 5,53260. Nilai rata-rata 4,2819200 dengan standar deviasi sebesar 1,26310389, dapat diartikan adanya variasi yang terdapat dalam BOPO. Angka 4,28199200 tersebut menunjukkan angka yang relatif besar karena simpangan baku pada BOPO lebih rendah dari 4,28199200 yaitu 1,26310389. Hal ini mengindikasikan bahwa tingkat efisiensi dan kemampuan bank dalam melakukan kegiatan operasinya kurang baik.

\section{Hasil Analisis Pengujian Data}

Uji Normalitas digunakan untuk menguji apakah dalam satu model regresi Variabel Independen dalam penelitian ini yang terdiri dari ROA, ROE, LBAP, NPM, BOPO memiliki distribusi normall atau tidak. Model regresi yang baik adalah model regresi yang terdistribusi normal. Uji nilai signifikansi lebih dari 0,05 maka dapat disimpulkan bahwa model regresi terdistribusi normal.

\section{Tabel 3. Uji Normalitas Dengan Pendekatan Laba Rugi}

\begin{tabular}{|c|c|c|c|c|c|c|}
\hline & & $\mathrm{ROA}$ & ROE & LBAP & NPM & BOPO \\
\hline \multirow[t]{2}{*}{$\mathrm{N}$} & & 5 & 5 & 5 & 5 & 5 \\
\hline & Mean & .0074400 & .0892600 & .6601000 &, 0993400 & 4,2819200 \\
\hline Normal & Std. Deviation & .00366647 & .04310985 & .32241093 & .05575184 & 1,26310389 \\
\hline \multicolumn{7}{|l|}{ Parametercs, } \\
\hline Most Extreme & Absolute & .254 & .241 &, 177 &, 244 & .255 \\
\hline \multirow[t]{2}{*}{ Differences } & Positive & .232 & .227 & .177 & .244 & .255 \\
\hline & Negative & -254 &,- 241 &,- 156 &,- 225 &,- 235 \\
\hline \multicolumn{2}{|l|}{ Test Statistic } & .254 & 241 & .177 & 244 & .255 \\
\hline \multicolumn{2}{|c|}{ Asyoun, Sig. (2-tailed) } & $200^{\mathrm{c}, \mathrm{d}}$ & $200^{c, d d}$ & $200^{c, d d}$ & $200^{c, d d}$ & $200 \stackrel{\mathrm{cod} d}{=}$ \\
\hline
\end{tabular}

Tabel 4.Uji Normalitas Dengan Pendekatan Nilai Tambah

\begin{tabular}{|c|c|c|c|c|c|c|}
\hline & & ROA & ROE & LBAP & NPM & BOPO \\
\hline $\mathrm{N}$ & & 5 & 5 & 5 & 5 & 5 \\
\hline \multirow[t]{2}{*}{ Normal Parameters ${ }^{a, b}$} & Mean & .7856800 & 9,5035000 & .5737600 & 10,1955200 & 4,2819200 \\
\hline & $\begin{array}{l}\text { Std. } \\
\text { Deviation }\end{array}$ &, 03850347 & ,63526882 & .02265972 & .40049488 & 1,26310389 \\
\hline Most Extreme & Absolute & .324 & .342 & 207 & .256 & .255 \\
\hline \multirow[t]{2}{*}{ Differences } & Positive & .255 &, 216 & .186 & .180 & .255 \\
\hline & Negative & -.324 &,- 342 & -.207 &,- 256 &,- 235 \\
\hline Test Statistic & & .324 &, 342 &, 207 & .256 & .255 \\
\hline Asyoun Sig. (2-tailed) & & $.093^{\mathrm{C}}$ & $.057^{\mathrm{C}}$ & $200^{\mathrm{c,d} d}$ & $200^{\mathrm{c}, \mathrm{d}}$ & 2000 \\
\hline
\end{tabular}

Berdasarkan Tabel 3. dalam uji normalitas menggunakan kolmogorov-smirnov dengan pendekatan laba rugi diperoleh hasil bahwa data berdistribusi normal. Hal ini dapat di lihat dari tingkat signifikansi pada rasio ROA, ROE, LBAP, NPM, dan BOPO
Financial Performance of Sharia Banking 
Financial Performance Analysis of Sharia Banking lebih besar dari 0,05 yaitu, ROA 0,200, ROE 0,200, LBAP 0,200, NPM 0,200 dan BOPO 0,200 .

Berdasarkan tabel 4. dalam uji normalitas kolmogorov-smirnov dengan pendekatan nilai tambah diperoleh hasil bahwa data berdistribusi normal. Hal ini dapat dilihat dari tingkat signifikansi untuk ROA, ROE, LBAP, NPM dan BOPO yaitu sebesar 0,093, 0,57, 0,200, $0,200,0,200$ yang artinya lebih besar dari 0,05 .

\section{Hasil Pengujian Hipotesis}

Pengujian hipotesis merupakan pengujian yang dilakukan untuk menjawab dugaan sementara atas masalah yang telah dirumuskan. Dalam penelitian ini digunakan pengujian Uji beda $t$ test yang merupakan bagian dari uji hipotesis komparatif atau uji perbandingan. Dalam penelitian ini uji $\mathrm{t}$ digunakan untuk mengetahui lebih lanjut perbandingan kinerja keuangan bank syariah mandiri dengan pendekatan laba rugi dan nilai tambah, maka dilakukan uji beda (uji-t) dengan pendekatan analisis Paired Sample Test, melalui perhitungan dari hasil program IBM SPSS Statistic 26.

Perbedaan pengaruh ROA terhadap kinerja keuangan PT. Bank Syariah Mandiri tahun 2016-2020 berdasarkan pendekatan laba rugi dan nilai tambah.

Tabel 5. Uji Beda T-test ROA

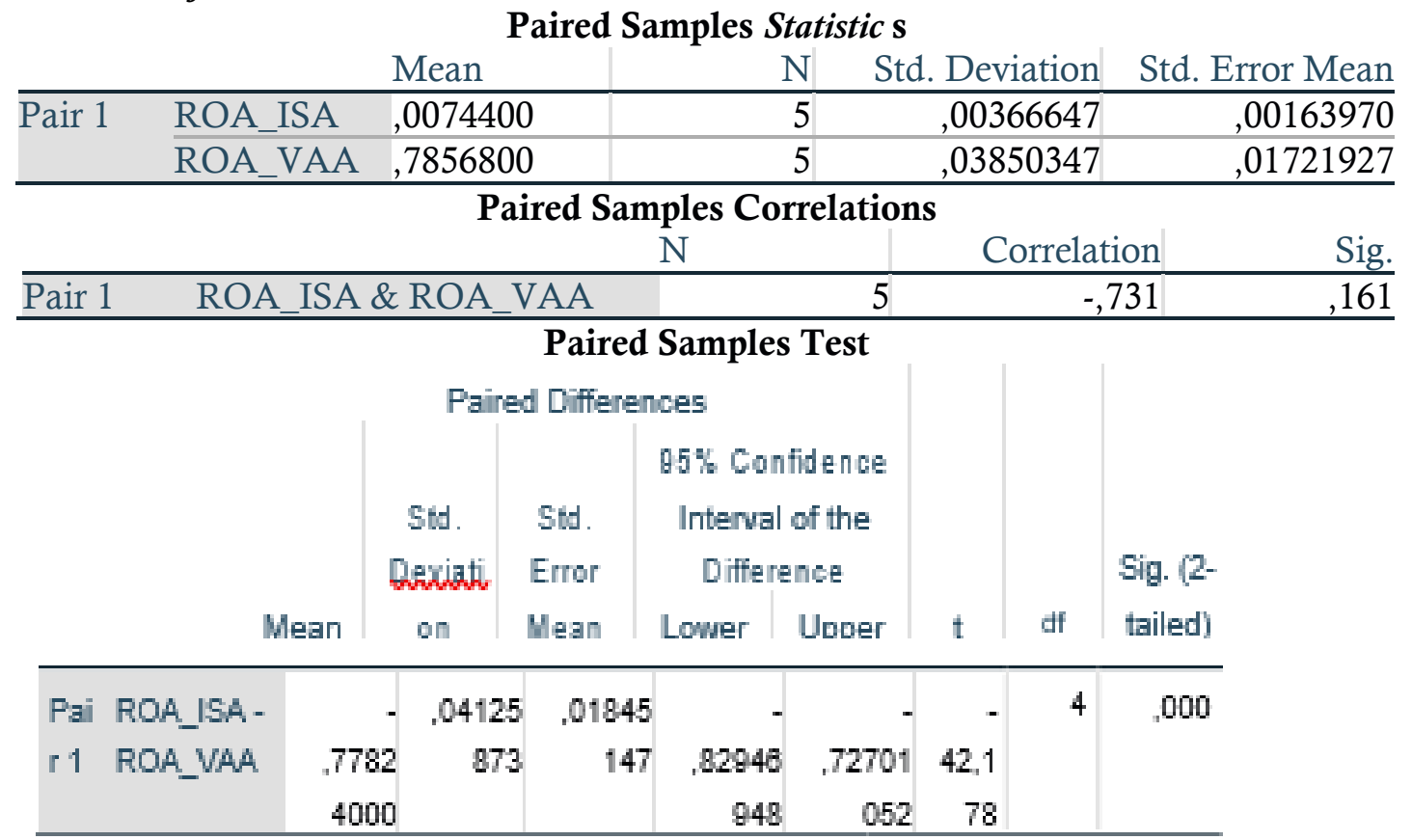

Berdasarkan tabel 5 dalam penelitian ini, menyatakan bahwa terdapat perbedaan yang signifikan pada rasio ROA berdasarkan pendekatan laba rugi dan nilai tambah pada PT. Bank Syariah Mandiri tahun 2016-2020 karena tingkat signifikansi ROA 0,000 yang artinya $<0,05$. Selain itu berdasarkan analisis deskriptif pada rasio ROA selama 5 periode penelitian dari dua pendekatan tersebut, secara kuantitatif nilai tambah memiliki rasio ROA yang lebih tinggi dibandingkan dengan laba rugi. Hal tersebut menggambarkan bahwa dengan pendekatan nilai tambah jumlah pendapatan PT. Bank Syariah Mandiri besar dikarenakan dalam nilai tambah bagian pihak ketiga atas bagi hasil merupakan gaji karyawan, zakat, dan pajak tidak mengurangi pendapatan yang diperoleh tetapi merupakan bagian dari pendistribusian pendapatan yang dihasilkan oleh bank syariah.

Perbedaan pengaruh ROE terhadap kinerja keuangan PT. Bank Syariah Mandiri tahun 2016-2020 berdasarkan pendekatan laba rugi dan nilai tambah

Berdasarkan tabel 6. dari hasil perhitungan spss dalam penelitian ini, hasil yang sama ditunjukkan pada rasio ROE yang membuktikkan bahwa terdapat perbedaan yang signifikan antara laba rugi dan nilai tambah pada PT. Bank Syariah Mandiri tahun 20162020 karena tingkat signifikansi ROE 0,000 yang artinya $<0,05$. Selain itu berdasarkan analisis deskriptif terhadap ROE selama 5 periode penelitian, dari kedua pendekatan 
tersebut secara kuantitatif nilai tambah memiliki rasio ROE yang lebih tinggi dibandingkan dengan laba rugi. Hal tersebut menggambarkan bahwa dengan pendekatan nilai tambah jumlah pendapatan PT. Bank Syariah Mandiri besar dikarenakan dalam nilai tambah bagian pihak ketiga tidak mengurangi pendapatan yang diperoleh tetapi merupakan bagian dari pendistribusian pendapatan atau bagi hasil.

Tabel 6. Uji Beda T-test ROE

\section{Paired Samples Statistic s}

\begin{tabular}{llrrrrr} 
& & Mean & N & Std. Deviation & Std. Error Mean \\
\hline Pair 1 & ROE_ISA &, 0892600 & 5 &, 04310995 &, 01927936 \\
\cline { 2 - 6 } & ROE_VAA & 9,5035000 & 5 &, 63526882 &, 28410085 \\
\hline \multicolumn{7}{c}{ Paired Samples Correlations } \\
& & N & Correlation & Sig. \\
\hline Pair 1 & ROE_ISA \& ROE_VAA & 5 &,- 668 &, 218 \\
\hline
\end{tabular}

\section{Paired Samples Test}

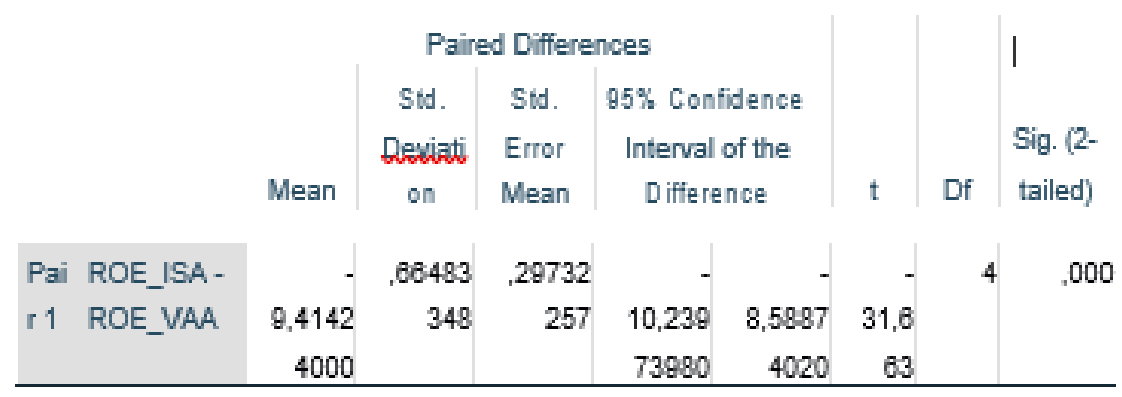

Perbedaan pengaruh LBAP terhadap kinerja keuangan PT. Bank Syariah Mandiri tahun 2016-2020 berdasarkan pendekatan laba rugi dan nilai tambah.

Tabel 7. Uji Beda T-test LBAP

Paired Samples Statistic s

\begin{tabular}{lll|rrr} 
& & Mean & N & Std. Deviation & Std. Error Mean \\
\hline Pair 1 & LBAP_ISA &, 6601000 & 5 &, 32241093 &, 14418655 \\
\cline { 2 - 6 } & LBAP_VAA &, 5737600 & 5 &, 02265972 &, 01013374 \\
\hline
\end{tabular}

Paired Samples Correlations

\begin{tabular}{llrrr} 
& $\mathrm{N}$ & Correlation & Sig. \\
\hline Pair 1 & LBAP_ISA \& LBAP_VAA & 5 &, 078 &, 901 \\
\hline
\end{tabular}

Paired Samples Test

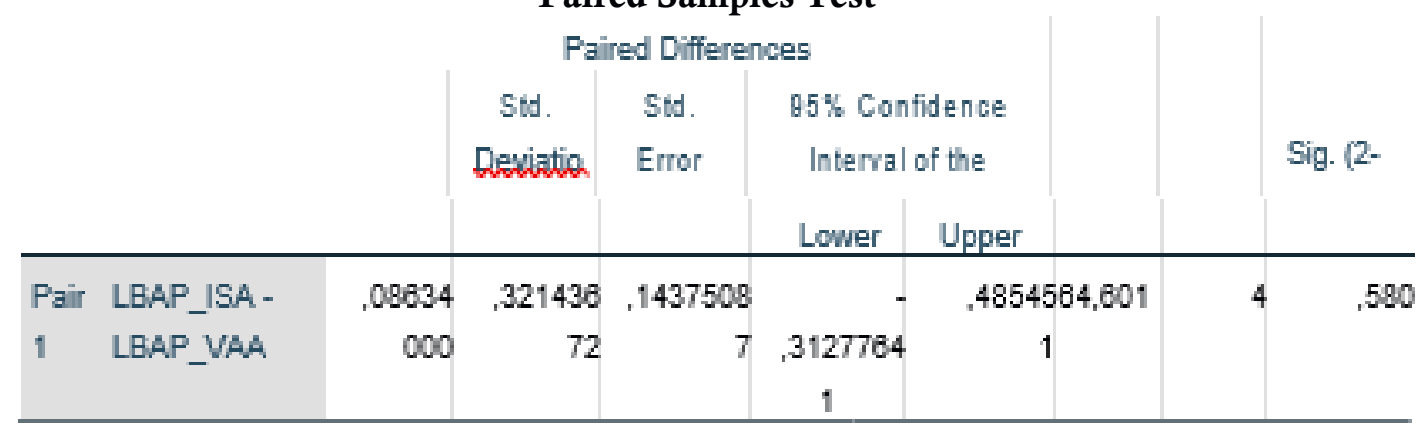

Berdasarkan tabel 7. dari hasil perhitungan spss dalam penelitian ini, hasil yang berbeda ditunjukkan pada rasio LBAP yang terbukti bahwa tidak terdapat perbedaan yang signifikan pada rasio LBAP antara pendekatan laba rugi dan nilai tambah pada PT. Bank Syariah Mandiri tahun 2016-2020 karena signifikansi LBAP 0,580 yang artinya > 0,05. Selain itu berdasarkan analisis deskriptif rasio LBAP selama 5 periode penelitian dari kedua pendekatan tersebut secara kuantitatif laba rugi memiliki rasio LBAP lebih tinggi dibandingkan dengan nilai tambah. Hal tersebut menggambarkan bahwa dengan
Financial Performance of Sharia Banking 
Financial Performance Analysis of Sharia Banking

$\underline{344}$

pendekatan laba rugi besarnya jumlah pendapatan PT. Bank Syariah Mandiri mengurangi pendapatan yang diperoleh oleh pihak ketiga.

Perbedaan pengaruh NPM terhadap kinerja keuangan PT. Bank Syariah Mandiri tahun 2016-2020 berdasarkan pendekatan laba rugi dan nilai tambah.

Tabel 8. Uji Beda T-test NPM

Paired Samples Statistic s

\begin{tabular}{llrrrr} 
& & Mean & N & Std. Deviation & Std. Error Mean \\
\hline Pair 1 & NPM_ISA &, 0993400 & 5 &, 05575184 &, 02493298 \\
\cline { 2 - 6 } & NPM_VAA & 10,1955200 & 5 &, 40049488 &, 17910675 \\
\hline
\end{tabular}

Paired Samples Correlations

\begin{tabular}{llrrrr} 
& \multicolumn{2}{c}{ Paired Samples Correlations } & N & Correlation & Sig. \\
\hline Pair 1 & NPM_ISA \& NPM_VAA & 5 &, 886 &, 045 \\
\hline
\end{tabular}

Paired Samples Test

\begin{tabular}{|c|c|c|c|c|c|c|c|c|}
\hline & \multicolumn{5}{|c|}{ Paired Differences } & \multirow[b]{3}{*}{$\mathrm{T}$} & \multirow[b]{3}{*}{ Df } & \multirow[t]{3}{*}{$\begin{array}{l}\text { Sig. (2- } \\
\text { tailed) }\end{array}$} \\
\hline & \multirow[b]{2}{*}{ Mean } & \multirow{2}{*}{$\begin{array}{c}\text { Sid. } \\
\text { Deviati } \\
\text { on }\end{array}$} & \multirow{2}{*}{$\begin{array}{l}\text { Std. } \\
\text { Error } \\
\text { Mean }\end{array}$} & \multicolumn{2}{|c|}{$\begin{array}{l}95 \% \text { Confidence } \\
\text { Interval of the } \\
\text { Difference }\end{array}$} & & & \\
\hline & & & & Lower & Upper & & & \\
\hline Pai NPM_ISA - & - & \multicolumn{2}{|c|}{$.35203 \quad 157433$} & & . & - & 4 & .000 \\
\hline r 1 NPM_VAA & 10,0961 & & & 10,5332 & 9,65907 & 64,1 & & \\
\hline & 8000 & & & & & 30 & & \\
\hline
\end{tabular}

Berdasarkan tabel 8. hasil spss dalam penelitian ini, menyatakan bahwa terdapat pada rasio NPM terdapat perbedaan yang signifikan antara laba rugi dan nilai tambah pada PT. Bank Syariah Mandiri tahun 2016-2020 karena tingkat signifikansi NPM 0,000 yang artinya $<0,05$. Selain itu berdasarkan analisis deskriptif terhadap rasio NPM selama 5 periode penelitian, dari kedua pendekatan tersebut secara kuantitatif nilai tambah memiliki rasio NPM yang lebih tinggi dibandingkan dengan laba rugi. Hal tersebut membuktikan bahwa dengan pendekatan nilai tambah, jumlah pendapatan PT. Bank Syariah Mandiri besar dikarenakan dalam nilai tambah bagian pihak ketiga tidak mengurangi pendapatan yang diperoleh tetapi merupakan bagian dari pendistribusian pendapatan yang dihasilkan oleh bank syariah.

Perbedaan pengaruh BOPO terhadap kinerja keuangan PT. Bank Syariah Mandiri tahun 2016-2020 berdasarkan pendekatan laba rugi dan nilai tambah.

Tabel 9.Uji Beda T-test BOPO

Paired Samples Statistic $\mathbf{S}$

\begin{tabular}{lll|rrr} 
& & Mean & N & Std. Deviation & Std. Error Mean \\
\hline Pair 1 & BOPO_ISA & $4,2819200^{\text {a }}$ & 5 & 1,26310389 &, 56487723 \\
\cline { 2 - 6 } & BOPO_VAA & $4,2819200^{\mathrm{a}}$ & 5 & 1,26310389 &, 56487723 \\
\hline
\end{tabular}

Berdasarkan tabel 9. hasil spss dalam penelitian ini, menunjukkan hasil yang berbeda pada rasio BOPO Paired Sample Correlations dan Paired Sample Test tidak muncul dikarenakan pada rasio BOPO pada tahun 2016-2020 berkaitan dengan besarnya rasio BOPO baik menggunakan laba rugi maupun nilai tambah memperoleh hasil yang sama (tidak ada perbedaan).

\section{Pembahasan Hasil Penelitian}

Pembahasan Hasil ROA

Berdasarkan hasil analisis data di atas, didapatkan bahwa terdapat perbedaan yang signifikan pada rasio ROA antara pendekatan laba rugi dan pendekatan nilai tambah pada tahun 2016-2020 karena tingkat signifikansi ROA $<0,05$, selain itu berdasarkan analisis deskriptif terhadap ROA selama periode penelitian dari dua pendekatan tersebut secara 
kuantitatif pendekatan nilai tambah lebih memiliki rasio ROA yang lebih tinggi dibandingkan dengan pendekatan laba rugi. Hal ini sejalan dengan penelitian Dimas dkk (2019) yang menyatakan bahwa adanya perbedaan yang signifikan terhadap rasio Return On Asset (ROA) dengan menggunakan analisis pendekatan Income Statement Approach dengan Value Added Approach. Rasio ROA digunakan untuk mengukur kemampuan manajemen bank dalam memperoleh keuntungan secara keseluruhan, sehingga semakin tinggi nilai ROA mengindikasikan bahwa bank telah mempunyai tingkat keuntungan yang besar dalam memanfaatkan asset yang dimiliki.

\section{Pembahasan Hasil ROE}

Hasil analisis pada rasio ROE menyatakan bahwa terdapat perbedaan yang signifikan pada rasio ROE yang dihitung dengan menggunakan pendekatan laba rugi dan nilai tambah pada periode penelitian karena tingkat signifikansi pada rasio ROE

$<\quad 0,05$, berdasarkan analisis deskriptif terhadap ROE selama periode penelitian dari kedua pendekatan tersebut secara kuantitatif nilai tambah memiliki ROE yang lebih tinggi dibandingkan dengan laba rugi. Hal ini sejalan dengan penelitian M. Amrullah (2014) yang menyatakan bahwa terdapat perbedaan yang signifikan terhadap rasio Return On Equity (ROE) dengan menggunakan pendekatan laba rugi (Income Statement) dan nilai tambah (Value Added Statement). Rasio ROE merupakan indicator penting bagi para pemegang saham dan calon investor untuk mengukur kemampuan bank dalam memperoleh laba bersih yang berkaitan dengan pembayaran deviden, semakin tinggi ROE maka semakin tinggi pula laba yang diperoleh sehingga meningkatkan kemampuan bank lebih baik.

\section{Pembahasan Hasil LBAP}

Hasil analisis pada rasio perbandingan laba bersih dengan aktiva produktif (LBAP) menyatakan bahwa tidak terdapat perbedaan yang signifikan pada rasio LBAP yang dihitung dengan menggunakan pendekatan laba rugi dan nilai tambah pada periode penelitian, karena tingkat signifikansi pada rasio LBAP $>0,05$, berdasarkan analisis deskriptifterhadap LBAP selama periode penelitian dari kedua pendekatan tersebut secara kuantitatif nilai tambah memiliki rasio perbandingan laba bersih dengan total aktiva produktif lebih tinggi di bandingkan dengan pendekatan laba rugi.

\section{Pembahasan Hasil NPM}

Hasil analisis pada rasio Net Profit Margin (NPM) menyatakan terdapat perbedaan yang signifikan pada rasio NPM yang dihitung dengan pendekatan laba rugi dan pendekatan nilai tambah pada periode penelitian karena tingkat signifikansi pada NPM < 0,05 . Selain itu berdasarkan analisis deskriptif terhadap NPM selama periode penelitian dari kedua pendekatan tersebut secara kuantitatif nilai tambah memiliki NPM lebih tinggi dibandingkan dengan laba rugi. Hal ini sejalan dengan penelitian Istikanah dkk (2014) NPM secara parsial pada tahun 2010-2012 dengan menggunakan pendekatan Value Added Statement lebih tinggi dibandingkan dengan menggunakan Income Statement. Rasio NPM digunakan untuk mengukur kemampuan perbankan dalam menghasilkan laba bersih ditinjau dari sudut operating incomenya, sehingga semakin tinggi rasio NPM suatu bank menunjukkan hasil yang semakin baik.

\section{Pembahasan Hasil BOPO}

Hasil analisis pada rasio BOPO menyatakan tidak terdapat perbedaan yang signifikan pada rasio BOPO yang dihitung dengan pendekatan laba rugi dan nilai tambah pada periode penelitian karena biaya operasional terhadap pendapatan operasional dalam nilai tambah bersifat tetap seperti yang diperlakukan dengan oleh laba rugi. Hal ini sejalan dengan penelitian Agus Rifai (2014) tidak terdapat perbedaan yang signifikan antara kinerja keuangan bank syariah dengan analisis pendekatan ISA dan VAR.

\section{PENUTUP}

Berdasarkan hasil pengujian, pengolahan dan analisis data menggunakan statistic yang mengacu pada masalah dan tujuan penelitian maka dapat ditarik kesimpulan dari hasil penelitian ini adalah sebagai berikut :

\section{Financial \\ Performance of Sharia Banking}


Financial

Performance Analysis of Sharia Banking

346
1) Terdapat perbedaan yang signifikan pada rasio ROA dengan pendekatan laba rugi dan nilai tambah, hal ini terlihat dari perhitungan nilai $t$-test yang menghasilkan signifikansi (sig) sebesar $0,000<0,05$.

2) Terdapat perbedaan yang signifikan pada rasio ROE dengan pendekatan laba rugi dan nilai tambah, hal ini terlihat dari perhitungan nilai t-test yang menghasilkan signifikansi (sig) sebesar $0,000<0,05$.

3) Tidak terdapat perbedaan yang signifikan pada rasio LBAP dengan pendekatan laba rugi dan nilai tambah, hal ini terlihat dari perhitungan nilai $t$-test yang menghasilkan signifikansi (sig) sebesar 0,580 >0,05.

4) Terdapat perbedaan yang signifikan pada rasio NPM dengan pendekatan laba rugi dan nilai tambah, hal ini terlihat dari perhitungan nilai $t$-test yang menghasilkan signifikansi (sig) sebesar $0,000<0,05$.

5) Tidak terdapat perbedaan yang signifikan pada rasio BOPO karena BOPO dalam nilai tambah bersifat tetap seperti yang diperlakukan oleh laba rugi.

\section{DAFTAR PUSTAKA}

Amrullah Reza , M., \& Adityawarman . (2014). Analisis Perbandingan Kinerja Keuangan Perbankan Syariah Menggunakan Pendekatan Laba Rugi (Income Statement) Dan Nilai Tambah (Value Added Statement). Semarang : Diponegoro Journal Of Accounting.

Ajmi, D. N., \& Iriyadi, I. (2018). Analisis Penentuan Tarif Rawat Inap dan Perhitungan Harga Pokok Pada Klinik Utama Rawat Inap dr.

Akbar, B., Aziz, H. A., Djazuli, A., Kowi, M., \& Amyar, F. (2018, February). Performance Effectiveness Measurement of Village Funding Management Using Fuzzy Inference System (FIS) Method. In Conference Proceedings Jakarta Indonesia, ICABE 2018.

Anshori , A. G. (31 Maret 2018 ). Perbankan Syariah Di Indonesia . Jakarta : UGM Press, Hal. 66 s.d 68 .

Anshori, A. G. (t.thn.). Perbankan Syariah Di Indonesia .

Ansori , M. (14 Januari 2020 ). Metode Penelitian Kuantitatif Edisi 2 . Airlangga University Press, Hal. 47 .

Aulia, S.E., M. Ak , F. U. (12 Maret 2020 ). Akuntansi Bank Syariah . Duta Media Publishing, Hal. 37 s.d 43 .

Dienislami Amantubillah, R. (2014 ). Analisis Perbandingan Kinerja Keuangan Bank Syariah Dengan Menggunakan Pendekatan Nilai Tambah Dan Laba Rugi. Surakarta : Naskah Publikasi .

Ghozali , I. (2016 ). Aplikasi Analisis Multivariate Dengan Program SPSS 23 Edisi Kedelapan . Semarang : Universitas Diponegoro .

Iriyadi, I., Setiawan, B., \& Sutarti, S. (2017). Pelatihan Analisis Data Penelitian (Primer Dan Sekunder) Bagi Mahasiswa Kesatuan. Jurnal Abdimas, 1(1), 1-4.

Istikanah , \& Nur Achadiyah , B. (2014 ). Analisis Perbandingan Kinerja Keuangan Dengan Pendekatan Income Statement Dan Value Added Statement Pada Unit Usaha Syariah. Malang : Jurnal Nominal / Volume Iii Nomor 2 / Tahun 2014.

Kurniawan, A. (2014). Pengolahan Riset Ekonomi Jadii Mudah Dengan IBM SPSS . Jakad Media Publishing, Hal. 49.

Pratama , D., \& Frastuti , M. (Januari - Juni 2020 ). Analisis Perbandingan Kinerja Keuangan Perbankan Syariah Dengan Menggunakan Pendekatan Laba (ISA) dan Pendekatan Nilai Tambah (VAA). Jurnal Akuntanika, Vol. 6 N0. 1 .

Rifai , A. (Maret 2013 ). Analisis Perbandingan Kinerja Keuangan Bank Syariah Dengan Menggunakan Pendekatan Income Statement (ISA) dan Value Added Reporting . Semarang : FE Unnes Kampus Sekaran .

Sugiyono, P. (2013). Metode Penelitian Bisnis . Bandung : ALFABETA, Hal. 13, 115, dan 116.

Suryanto , T. (2016). Audit Delay And Its Implication For Fraudulent Financial Reporting. European Research Studies . 